\title{
Structural Quality of a Latosol Cultivated with Oilseed in Succession to Corn
}

\author{
Anderson Cristian Bergamin 1 , Antonio Carlos Tadeu Vitorino², Eber \\ Augusto Ferreira do Prado ${ }^{2}$, Fábio Régis de Souza ${ }^{1}$, Munir Mauad², and \\ Luiz Carlos Ferreira de Souza ${ }^{2}$ \\ ${ }^{1}$ Universidade Federal de Rondônia, Departamento de Agronomia, Campus de Rolim de Moura, Rolim de \\ Moura, Rondônia, Brasil. \\ ${ }^{2}$ Universidade Federal da Grande Dourados, Faculdade de Ciências Agrárias. Dourados, Mato Grosso do \\ Sul, Brasil.
}

\begin{abstract}
A.C. Bergamin, A.C.T. Vitorino, E.A.F. Prado, F.R. Souza, M. Mauad, and L.C.F. Souza. 2018. Structural Quality of a Latosol Cultivated with Oilseed in Succession to Corn. Cien. Inv. Agr. 45(2): 169-180. Mechanized operations on soils with inadequate moisture cause compaction and are deleterious to soil quality. The aim of this study was to evaluate the influence of different oilseed crop successions on the structural quality of a clayey Rhodic Hapludox. Sunflower (Helianthus annuus L.), canola (Brassica napus L. and Brassica rapa), safflower (Carthamus tinctorius L.), crambe (Crambe abyssinica Hochst.), and niger (Guizotia abyssinica) were sown in autumn/winter in a no-tillage system in succession to corn grown in the summer and soybean/corn grown in summer/autumn-winter. When the autumn-winter crops began to grow, soil samples were collected in metallic cylinders at $0.0-0.05 \mathrm{~m}$ and $0.05-0.10 \mathrm{~m}$ depths. Analyses of the optimal water interval in each crop succession at the $0.0-0.05 \mathrm{~m}$ layer indicated that the corn/safflower and corn/crambe successions reduced the structural quality of the soil. The autumn-winter niger crop in succession to summer corn improved the soil structure at $0.0-0.05 \mathrm{~m}$ and $0.05-0.10 \mathrm{~m}$ when compared with the soil cultivated with the soybean/corn succession. The niger crop is an effective crop rotation alternative that improves the physical quality of the soil under no-tillage systems.
\end{abstract}

Keywords: Preconsolidation pressure, soil compaction, soil penetration resistance.

\section{Introduction}

Different crop production systems modify the soil structure and therefore alter several physical, chemical, and biological properties. According to Safadoust et al. (2014), because both internal and external factors affect soil porosity and function,

Received Jun 30, 2017. Accepted Mar 20, 2018.

Corresponding author: eberprado@hotmail.cl crop management may modify soil particle configuration and alter its physical quality. Therefore, conservationist methods such as the no-tillage system (NTS) should be used because they maintain plant cover and residues on the soil surface, typically include crop rotation and minimize soil turnover during sowing. These strategies increase the sustainability of agricultural systems (Franchini et al., 2012). 
The three pillars of the no-tillage system (NTS) are soil cover, crop rotation, and minimum turnover during sowing. The first two factors are closely related; they determine NTS success and depend primarily on appropriate crop selection. Under the edaphoclimatic conditions of hot, rainy summers and dry winters, it is difficult to select autumn-winter crops.

Changes in the physical properties of soil are both complex and dynamic. Therefore, it is difficult to assess soil structure transformations caused by management techniques. The least limiting water range (LLWR) integrates physical- and water-related properties related to root growth, soil water availability, and plant development (Mishra et al., 2015). Studies have shown that LLWR is an effective indicator of change in the physical properties of the soil under different usage and management systems (Garbiate et al., 2016).

Soil compression curves have also been used to identify structural changes in the soil caused by compaction. Modeling evaluates load-bearing capacity (LBC), which indicates the maximum pressure that the soil can bear under different moisture levels without increasing compaction (Pereira et al., 2015).

Soil density (Ds) is included in the LBC model because it reflects the soil compaction state and increases model reliability in predicting responses to conditions that restrict root growth. LLWR could also be included in the LBC model, which could indicate the critical pressure for plant growth. Imhoff et al. (2016) defined it as the maximum pressure that can be applied to the soil without root growth restriction or aggravation of existing soil deformation.

The aim of this study was to use LLWR and LBC models to assess the impact of various autumnwinter oilseed crops sown in succession to summer corn with a no-tillage system in a clayey Rhodic Hapludox.

\section{Materials and methods}

\section{Characterization of the study area}

The study was conducted in the municipality of Dourados in Mato Grosso do Sul, Brazil at a latitude/longitude of $22^{\circ} 13^{\prime} 58^{\prime}$ 'S/ $54^{\circ} 59^{\prime} 30^{\prime \prime} \mathrm{W}$ and an altitude of $410 \mathrm{~m}$. The climate is Cwa (humid mesothermal, with rainy summers and dry winters) according to the Köppen classification. The average annual rainfall in the region is $1,378 \mathrm{~mm}$, and the average temperature is $22.2^{\circ} \mathrm{C}$, which varies from 17.7 to $25.3{ }^{\circ} \mathrm{C}$ in the coldest and hottest months, respectively.

The soil in the experimental area was classified as a clayey Rhodic Hapludox, according to the soil taxonomy system (Soil Survey Staff, 2014), and as a Latossolo Vermelho Distrófico típico (LVd), according to the Brazilian soil classification system. The particle size distribution, which was determined through the pipette method (Teixeira et al., 2017), was $531 \mathrm{~g} \mathrm{~kg}^{-1}$ clay, $249 \mathrm{~g} \mathrm{~kg}^{-1}$ silt, and $220 \mathrm{~g} \mathrm{~kg}^{-1}$ sand.

For 10 years prior to the experiment, the area was managed by a no-tillage crop-rotation system involving corn or soybean in spring-summer and a second corn crop and oats in autumnwinter. The experiment was performed using a completely randomized design with five treatments (sunflower (Helianthus annuus L.), canola (Brassica napus L. and Brassica rapa), safflower (Carthamus tinctorius L.), crambe (Crambe abyssinica Hochst.), and niger (Guizotia abyssinica)) with four replications. A no-tillage system was used. The autumn-winter oilseeds were planted in succession to the summer corn.

Corn (cv. DKB 390 YG) was sown in four lines spaced $0.90 \mathrm{~m}$ apart using a no-tillage seederfertilizer, of the SEMEATO brand (Passo Fundo - RS, Brazil), model SHM 15/17. Seeds were sown at a rate sufficient to make a density of sixty thousand plants per hectare. A $0.3 \mathrm{Mg} \mathrm{ha}^{-1}$ 10-20-20 (NPK) formula was used to fertilize the 
seeds. The oilseed crops were seeded mechanically in seven lines spaced $0.45 \mathrm{~m}$ apart using a no-tillage seeder-fertilizer. They were sown in autumn-winter in rotation with the summer corn. The 10-20-20 seed fertilizer dosage was adjusted to apply $0.2 \mathrm{Mg} \mathrm{ha}^{-1}$.

Selection, collection and preparation of soil samples

When the autumn-winter crops began to grow, soil samples were collected with structures intact in metal cylinders $6.45 \mathrm{~cm}$ in diameter and 2.54 $\mathrm{cm}$ in height. The cylinders were inserted in the middle of the $0-5 \mathrm{~cm}$ and $5-10 \mathrm{~cm}$ soil layers.

\section{Analytical procedures}

Samples were taken between crop furrows. The plots measured $35 \mathrm{~m}$ in length and $14 \mathrm{~m}$ in width $\left(\right.$ area $\left.=490 \mathrm{~m}^{2}\right)$. Seven samples were collected from each plot at each depth. Fifty-six samples were collected per treatment ( 28 samples/depth $\times 2$ depths).

Once prepared, the samples were saturated in a tray by gradually adding water until $\sim 2 / 3$ of the height of the ring was reached. The 28 samples from each treatment and depth were divided into seven groups of four samples. Using a tension table (-0.006 MPa), each group was subjected to the following matric potentials: $-0.006,-0.01$, $-0.033,-0.066,-0.1,-0.3$, and -1.5 Mpa. A Richards chamber was used for the other potentials. Microporosity was determined using the tension table $(-0.006 \mathrm{MPa})$ as described in Teixeira et al. (2017).

After reaching equilibrium under stress, the samples were weighed. The soil penetration resistance was determined using an electronic penetrograph with a constant penetration speed of $1 \mathrm{~cm} \mathrm{~min}^{-1}$, a rod base diameter of $4 \mathrm{~mm}$ and a $30^{\circ}$ semiangle. The values obtained for the upper and lower 5 $\mathrm{mm}$ of the sample were discarded to eliminate the peripheral region effect. Soil penetration resistance readings were taken every 0.25 seconds. Six hundred readings were obtained per sample, and the means were calculated. The samples were then placed in an oven at $105-110^{\circ} \mathrm{C}$ for $48 \mathrm{~h}$ to determine volumetric moisture content and soil density via the volumetric ring method. Total porosity and macroporosity were also measured according to Teixeira et al., 2017. The LLWR was determined as described by Silva et al. (1994). The critical values of water content associated with the soil matric potential, penetration resistance and aeration porosity, were measured respectively by water content at field capacity $(\theta \mathrm{FC})$, potential of $-0.01 \mathrm{MPa}$, the water content at the permanent wilting point $(\theta \mathrm{PWP})$, potential of $-1.5 \mathrm{MPa}$, the volumetric water content of the soil in which the soil penetration resistance $(\theta \mathrm{PR})$ reaches 2.0 $\mathrm{MPa}$ and the volumetric water content at which air-filled porosity $(\theta \mathrm{AP})$ is $0.10 \mathrm{~m} 3 \mathrm{~m}-3$.

The $\theta_{\mathrm{FC}}$ and $\theta_{\mathrm{PWP}}$ values were calculated by the mathematical model $\left[\theta=\exp ^{(a+b D s)}{ }_{\psi}^{c}\right]$ proposed by Silva et al. 1994. The original data fit and incorporated soil density into the function. $\theta$ is the soil volumetric moisture content $\left(\mathrm{m}^{3} \mathrm{~m}^{-3}\right)$. Ds is the soil density $\left(\mathrm{Mg} \mathrm{m}^{-3}\right)$, which is the relationship between the mass of dry soil and its total volume, that is, the volume of the soil including the spaces occupied by water and air. $\Psi$ is the matric potential (Mpa), and "a," "b," and "c" are empirical model fitting parameters.

PR values from all the samples whose $\theta$ and Ds were known were mathematically fit using the model $\left[P R=d \theta^{e} D^{f}\right]$. PR is the soil penetration resistance (Mpa), $\theta$ is the soil volumetric moisture content $\left(\mathrm{m}^{3} \mathrm{~m}^{-3}\right)$, Ds is the soil density $\left(\mathrm{Mg} \mathrm{m}^{-3}\right)$, and "d," "e," and "f" are empirical model fitting parameters. Using this model, it was possible to determine the critical $\theta$, such that $\mathrm{PR} \leq 2.0 \mathrm{MPa}$ $\left(\theta_{\mathrm{PR}}\right)$ according to Ds. PR was substituted with the threshold value $2.0 \mathrm{Mpa}$ in the model to calculate LLWR. 
$\theta_{\mathrm{AP}}$ was obtained by applying the model $\left[\theta_{\mathrm{AP}}=(1-\right.$ $(\mathrm{Ds} / \mathrm{Dp}))-0.10]$, where $\theta_{\mathrm{AP}}$ is the soil volumetric water content when the aeration porosity is 0.10 $\mathrm{m}^{3} \mathrm{~m}^{-3}$, Ds is the soil density $\left(\mathrm{Mg} \mathrm{m}^{-3}\right)$, and $\mathrm{Dp}$ is the particle density $\left(\mathrm{Mg} \mathrm{m}^{-3}\right)$. The mean particle density was set as $2.65 \mathrm{Mg} \mathrm{m}^{-3}$.

Either $\theta_{\mathrm{FC}}$ or $\theta_{\mathrm{AP}}$, adequate for crop growth and development, was considered to determine the upper LLWR limits. Either $\theta_{\mathrm{PWP}}$ or $\theta_{\mathrm{PR}}$, which limits plant growth and development, was considered for the lower LLWR limits. The critical soil density was then calculated. This is the soil density at which LLWR equals 0 , that is, when the upper limit of LLWR is numerically equivalent to its lower limit (Silva et al., 1994).

The mathematical models were fit, and "a," "b," "c," "d," "e," and "f $f$ " were obtained using a nonlinear regression model.

When the stressed samples reached equilibrium, they were subjected to uniaxial compression tests using an automatic consolidometer (Model CNTA-IHM/BR-001/07). The following pressures were applied to each sample: $25,50,100$, $200,400,800$, and 1,600 $\mathrm{kPa}$. Each pressure was applied until $90 \%$ of the maximum deformation was reached. The samples were then placed in an oven at $105-110^{\circ} \mathrm{C}$ for $48 \mathrm{~h}$ to determine their volumetric moisture content and soil density using the volumetric ring method (Teixeira et al., 2017).

The soil compression curve was obtained by plotting the pressures on the abscissa and the soil density at each pressure application stage on the ordinate. The load bearing capacity $\left(\sigma_{p}\right)$ was determined for each sample using the method proposed by Dias Junior and Pierce (1995). The $\sigma_{p}$ and the volumetric moisture content $(\theta)$ values were fit to a decreasing exponential regression $\left[\sigma_{p}=10^{(a+b \theta)}\right]$. In this way, the LBC models were determined. The letters " $a$ " and " $b$ " represent the empirical model fitting parameters, namely, the linear and angular coefficients, respectively.
The models were compared by the homogeneity test of linear models described by Snedecor and Cochran (1989). A logarithm was applied to the preconsolidation pressure values to obtain the linear models from the exponential model $[\sigma p=$ $10\left({ }^{a+b \theta}\right)$ ], resulting in the equation $\sigma p=a+\log$ $b \theta$. The homogeneity test of linear model considers two models, which were compared by the analysis of the intercept "a", slope "b" and data homogeneity (F).

\section{Results and Discussion}

The fit curves for water retention and soil penetration resistance had coefficients of determination $\left(\mathrm{R}^{2}\right)$ significant at the $1 \%$ level, determined by the $F$-test. It is clear that the adjustment coefficients for the water retention curve in the soil were statistically significant $(\mathrm{p}<0.01)$ because the confidence interval for the coefficients does not include the value zero, except for coefficient "b", which was not significant in the $0.05-0.10 \mathrm{~m}$ layer for the corn/sunflower or the corn/canola successions (Blainski et al., 2009; 2012).

The soil water retention curve was statistically significant and influenced positively by Ds and negatively by $\Psi$. These findings corroborate those reported by Garbiate et al. (2016). According to Blainski et al. (2009; 2012), at high matric potentials, pore sizes are changed. There is an increase in the number of small diameter pores, and the soil retains water more efficiently. As the soil dries, however, Ds (solid mass per area unit) increases, which causes $\theta$ to increase as well.

The confidence intervals for fitting "e" and " $\mathrm{f}$ " on the soil penetration resistance curve do not include zero, so they are statistically significant $(p<0.01)$. Coefficient "d" was significant $(p<0.01)$ only in the corn/safflower succession models at $0.0-0.05$ $\mathrm{m}$ and the corn/safflower succession model at $0.05-0.10 \mathrm{~m}$ because the confidence interval for "d" does not include zero. In the other successions, the confidence intervals for "d" did include zero 
and were therefore not significant according to Blainski et al. (2009) and Blainski et al. (2012).

At the $0.00-0.05 \mathrm{~m}$ layer, the corn/canola treatment resulted in relatively low LLWR at the lower soil densities. Depending on the soil density, LLWR ranged from $0.025-0.13 \mathrm{~m}^{3} \mathrm{~m}^{-3}$ for corn/ sunflower, $0.03-0.14 \mathrm{~m}^{3} \mathrm{~m}^{-3}$ for corn/canola, 0.02 $0.15 \mathrm{~m}^{3} \mathrm{~m}^{-3}$ for corn/safflower, $0.00-0.14 \mathrm{~m}^{3} \mathrm{~m}^{-3}$ for corn/crambe, and $0.00-0.16 \mathrm{~m}^{3} \mathrm{~m}^{-3}$ for corn/ niger (Figure 1A).

In the $0.05-0.10 \mathrm{~m}$ layer, LLWR ranged from 0.00-0.09 $\mathrm{m}^{3} \mathrm{~m}^{-3}$ for corn/sunflower, 0.00-0.06 $\mathrm{m}^{3} \mathrm{~m}^{-3}$ for corn/canola, $0.00-0.08 \mathrm{~m}^{3} \mathrm{~m}^{-3}$ for corn/ safflower, $0.00-0.09 \mathrm{~m}^{3} \mathrm{~m}^{-3}$ for corn/crambe, and $0.00-0.11 \mathrm{~m}^{3} \mathrm{~m}^{-3}$ for corn/niger (Figure 1B).

The coefficients of determination $\left(\mathrm{R}^{2}\right)$ for all curves fit from the LBC models were significant at the $1 \%$ level, determined by the $F$-test, and ranged from 0.76-0.96.

Despite the fact that the fit in modeling soil compression behavior has not been applied, this proposal is accepted because the regressions are statistically significant. Blainski et al. (2009) and Blainski et al. (2012) indicated that when the LBC model coefficient confidence intervals did not include zero, they were considered statistically significant.
The LBC models were compared using the linear model homogeneity test (Snedecor and Cochran, 1989) for the different soil layers by each crop to determine the possible soil structure changes caused by the different crops. In the $0.00-0.05$ $m$ layer, the LBC models were homogeneous $(\mathrm{H})$ for the corn/sunflower and corn/canola treatments and showed no difference in LBC between them. For the other treatments at the $0.00-0.05$ $\mathrm{m}$ and $0.05-0.10 \mathrm{~m}$ layers, the homogeneity test showed differences in soil compression behavior among them, and therefore, they were not homogeneous (NH).

Non-homogeneity is due to increased contact between soil particles, greater internal friction in the soil, and higher preconsolidation pressure values. These are the result of high initial soil density (1.50 $\mathrm{Mg} \mathrm{m}^{-3}$ ). Comparisons between LBC models for the $0.00-0.05 \mathrm{~m}$ layer rotations that were not different according to the $F$-test were fit using a single equation for all $\sigma_{\mathrm{p}}$ and $\theta$. In this way, a single LBC model was derived for these crops.

Comparisons between LBC models for the crops in both layers that were different according to the $F$-test did not show any grouping. In all LBC models for the crops studied, $\sigma_{p}$ varied significantly and inversely with $\theta$ at the $0.00-0.05 \mathrm{~m}$ and $0.05-0.10 \mathrm{~m}$ layers.

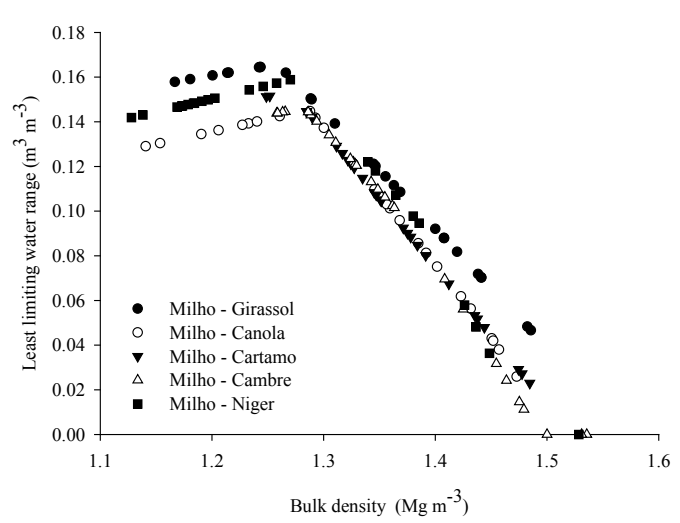



Figure 1. Variations in LLWR according to the density of a dystroferric Red Latosol at $0.00-0.05 \mathrm{~m}$ (A) and $0.05-0.10 \mathrm{~m}$ (B) cultivated with different crop successions. 
Soil densities (Ds) were incorporated into LLWR and LBC output by modeling the data on a 3-D response surface to determine the water content and soil pressures that do not reduce corn root growth and crop yield.

The incorporation of Ds in the LBC model (Imhoff et al., 2001) increases data reliability, shows high $\mathrm{R}^{2}$ values, and indicates that the equations were highly statistically significant $(p<0.0001)$ for the treatments at the $0.00-0.05 \mathrm{~m}$ layers, as shown in equations 1 to 4 below:

$\sigma_{\mathrm{p}}=\mathrm{P} 191065,836-(2063,516 \mathrm{x} \theta)+(209,597 \mathrm{x}$ Ds) $\mathrm{R}^{2}=0.91$ (1)

$\sigma_{\mathrm{p}}=\mathrm{P} 211062,689-(2330,161 \times \theta)+(231,129 \mathrm{x}$ Ds) $\mathrm{R}^{2}=0.88(2)$

$\sigma_{\mathrm{p}}=\mathrm{P} 22601,295-(1619,747 \times 0)+(275,914 \mathrm{x}$ Ds) $\mathrm{R}^{2}=0.88$ (3)

$\sigma_{\mathrm{p}}=\mathrm{P} 15+16790,445-(2190,989 \times 0)+(368,529$ x Ds) $\mathrm{R}^{2}=0.94$ (4)

For the $0.05-0.10 \mathrm{~m}$ layer, the equations and values of $\mathrm{R}^{2}$ are shown in equations 5 to 9 :

$\sigma_{\mathrm{p}}=\mathrm{P} 152030,083-(4604,977 \mathrm{x} \theta)+(210,862 \mathrm{x}$ Ds) $\mathrm{R}^{2}=0.92(5)$

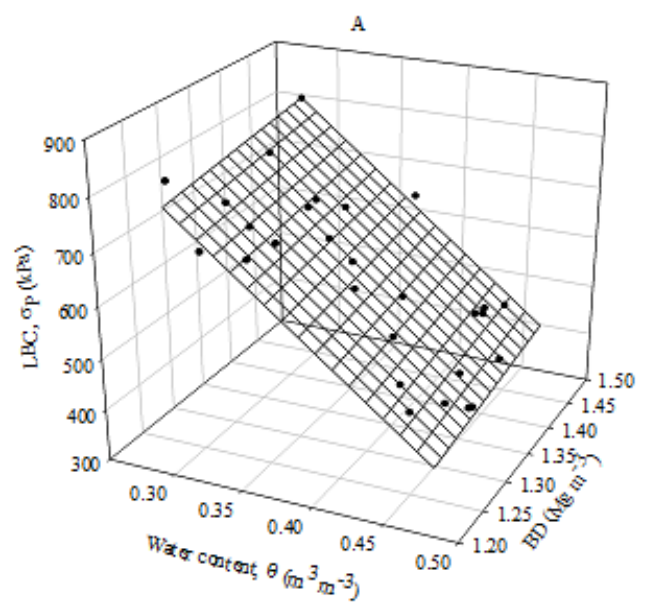

$\sigma_{\mathrm{p}}=\mathrm{P} 162068,083-(4613,346 \times 0)+(198,496 \times$ Ds) $\mathrm{R}^{2}=0.94(6)$

$\sigma_{\mathrm{p}}=\mathrm{P} 191147,18-(4341,363 \times 0)+(757,069 \mathrm{x}$ Ds) $\mathrm{R}^{2}=0.95(7)$

$\sigma_{\mathrm{p}}=\mathrm{P} 21653,832-(3481,616 \mathrm{x} \theta)+(875,614 \mathrm{x}$ Ds) $\mathrm{R}^{2}=0.90(8)$

$\sigma_{p}=P 221047,374-(3347,998 \times 0)+(484,185 \times$ Ds) $\mathrm{R}^{2}=0.90(9)$

Variations in the LBC incorporating Ds and moisture content are shown in Figures 2 and 3 (3D).

Soil load-bearing capacity decreases with increasing soil water content, and soil resistance to deformation increases with decreasing soil water content. The increase in Ds increases both the friction and points of contact between the particles and decreases the capacity for movement (Imhoff et al., 2001). As a result, the load-bearing capacity increases, and the water content decreases (Figures 2 and 3).

Soil density is indicative of soil compaction and accounts for both soil properties (such as texture) and management practices. Therefore, the use of Ds in the calculation of $\sigma_{p}$ defines LBC and considers the soil structural quality for plant growth (Imhoff et al., 2001).

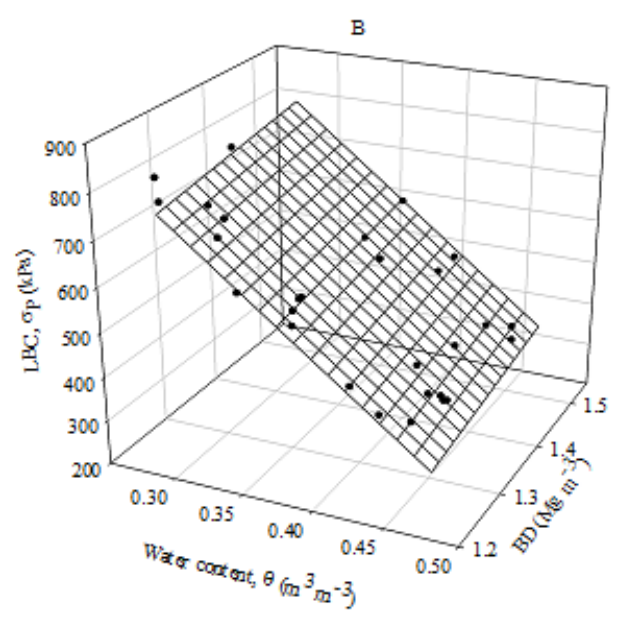



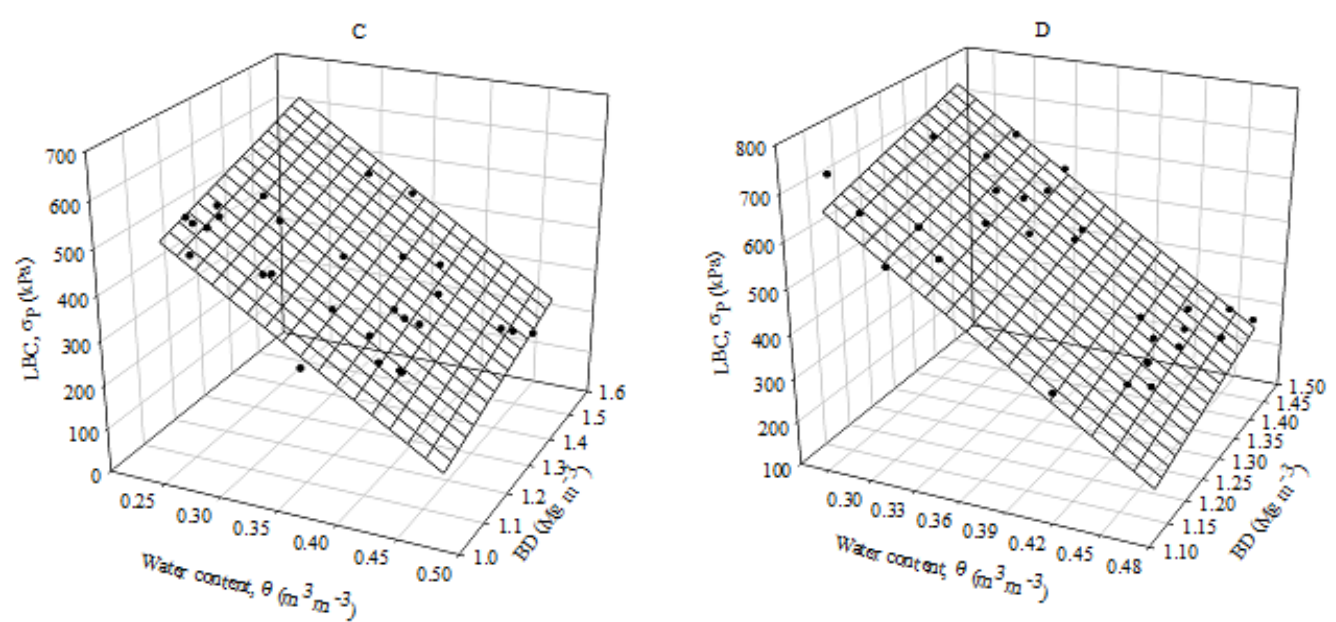

Figure 2. Variation in the LBC values incorporating water content $(\theta)$ and soil density (Ds) of a dystroferric Red Latosol at the $0.00-0.05$ m layer cultivated with different successions. (A) Corn - Sunflower $=$ Corn - Canola, (B) Corn - Safflower, (C) Corn - Crambe, and (D) Corn - Niger.

Ds was used to estimate LBC. Given that $\sigma_{\mathrm{p}}$ also varies with soil water content, relevant moisture content values had to be defined (Imhoff et al., 2001). Moisture values that incorporate plant growth-limiting factors along with aeration, available water, and soil penetration resistance ranged from $0.15-0.50 \mathrm{~m}^{3} \mathrm{~m}^{-3}$ in both the $0.00-0.05 \mathrm{~m}$ and $0.05-0.10 \mathrm{~m}$ soil layers.
For both the upper and lower LLWR intervals, LSC in the 0.00-0.05 $\mathrm{m}$ layer decreased with increasing in soil water content and ranged from 358.95-1081.18, 255.86-1071.41, 219.09785.99 , and $266.17-1033.02 \mathrm{kPa}$ in the corn/ sunflower or corn/canola, corn/safflower, corn/crambe, and corn/niger treatments, respectively (Figure 4).


Figure 3. Variation in the LBC values incorporating water content $(\theta)$ and soil density (Ds) of a dystroferric Red Latosol at the 0.05-0.10 m layer cultivated with different successions. (A) Corn - Sunflower (B) Corn - Canola, (C) Corn - Cartamo, (D) Corn - Crambe, and (E) Corn - Niger. 
In the $0.05-0.10 \mathrm{~m}$ layer, $\mathrm{LBC}$ decreased with increasing soil water content between the lower and upper LLWR intervals. LBC ranged from 54.43-1666.17, 69.08-1683.75, 149.96-1669.43, $270.23-1488.79$, and $123.86-1295.66 \mathrm{kPa}$, in the corn/sunflower, corn/canola, corn/safflower, corn/ crambe, and corn/niger treatments, respectively (Figure 5).

When the water content amplitude from the LLWR is considered $\left(0.24-0.36 \mathrm{~m}^{3} \mathrm{~m}^{-3}\right.$ in the $0.00-0.05$ $\mathrm{m}$ layer and $0.31-0.38 \mathrm{~m}^{3} \mathrm{~m}^{-3}$ in the $0.05-0.10 \mathrm{~m}$ layer for the rotations following corn), the LBC range can be determined. It represents the critical pressures for plant growth (Imhoff et al., 2001). Pcr is defined as the maximum pressure that can be applied to the soil without restricting root growth or causing additional soil deformation (Imhoff et al., 2001).

The Pcr interval (maximum LLWR amplitude) ranges from $572.91-835.83 \mathrm{kPa}$ for corn/sunflower and corn/canola, $647.85-874.83 \mathrm{kPa}$ for corn/safflower, $586.08-861.70 \mathrm{kPa}$ for corn/crambe, and $445.85-640.22 \mathrm{kPa}$ for corn/niger in the $0.00-0.05$ $\mathrm{m}$ soil layer (Figure 4). For the $0.05-0.10 \mathrm{~m}$ soil layer, the LLWR amplitude ranges from 607.03$929.38 \mathrm{kPa}$ for corn/sunflower, 622.68-945.61 $\mathrm{kPa}$ for corn/canola, 670.92-974.81 kPa for corn/ safflower, 688.02-931.73 kPa for corn/crambe, and 525.62-759.98 kPa for corn/niger (Figure 5).

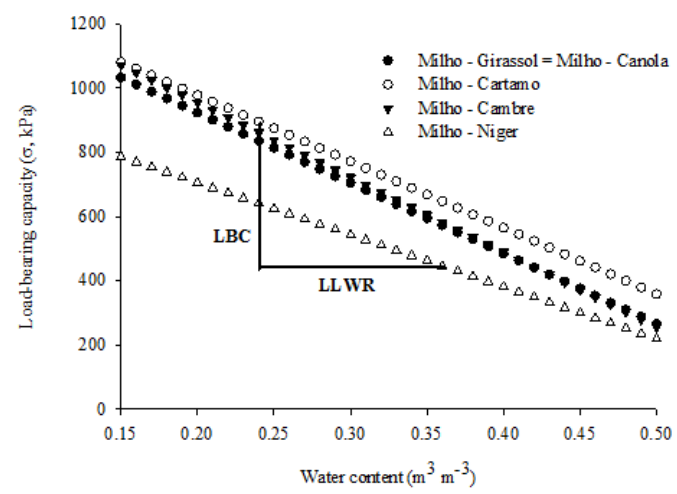

Figure 4. Variation in LBC with water content in the $0.0-0.05$ $\mathrm{m}$ layer of a dystroferric Red Latosol cultivated with different crop successions. Critical soil density $=1.55 \mathrm{Mg} \mathrm{m}^{-3}$.
In the LBC models for all crop successions, $\sigma_{\mathrm{p}}$ varied significantly and inversely with $\theta$ (Figures 4 and 5). $\sigma_{p}$ increased as the soil became drier because water decreases the cohesion between solid particles and forms films on them, thereby reducing friction (Pacheco and Cantalice, 2011). $\sigma_{p}$ decreased logarithmically with increasing $\theta$ (Figure 3 ).

The relative magnitudes of LBC for the $0.00-0.05$ $\mathrm{m}$ layer were as follows: corn/safflower > corn/ crambe $>$ corn/sunflower $=$ corn/canola $>$ corn/ niger (Figure 4).

LBC was highest for the soil under the corn/safflower and corn/crambe successions throughout the entire moisture content interval (Figure 4). Variations in LBC were likely due to differences in soil density in each crop succession. When the particles are closer together, macroporosity is reduced, and $\mathrm{LBC}$ is increased. The increase in LBC with initial soil density was also reported by Araujo-Junior et al. (2011), Pacheco and Cantalice (2011), and Souza et al. (2012).

In the $0.00-0.05 \mathrm{~m}$ layer, the corn/safflower, corn/ crambe, and corn/sunflower $=$ corn/canola successions had the highest LBC (Figure 4). High densities may reduce the susceptibility of the soil to compaction but may also limit root growth (Bergamin et al., 2010). Monitoring soil moisture content and performing mechanized activities at a subthreshold

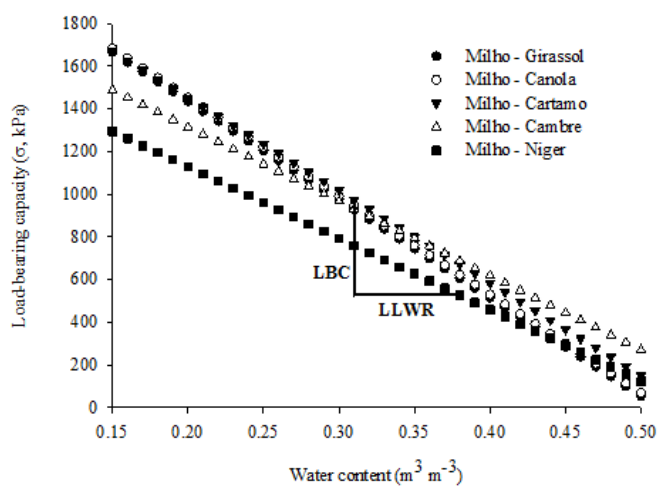

Figure 5. Variation in LBC with water content in the $0.0-0.05$ $\mathrm{m}$ layer of a dystroferric Red Latosol cultivated with different crop successions. Critical soil density $=1.55 \mathrm{Mg} \mathrm{m}^{-3}$. 
moisture content level (indicated by the LBC model) are sufficient to reduce the risk of compaction by machinery traffic (Souza et al., 2012).

For example, a self-propelled sprayer (4 x 2) exerts $452 \mathrm{kPa}$ of pressure in one pass over the soil surface (Silva et al., 2006). Based on the SBC, it should ideally be deployed only when the soil moisture content is lower than $0.29,0.37,0.38,0.39$, and $0.44 \mathrm{~m}^{3} \mathrm{~m}^{-3}$ in the corn/niger, corn/sunflower or corn/canola, soybean/sunflower, corn/crambe, and corn/safflower successions, respectively (Figure 4), to avoid additional compaction in the $0.00-0.05$ $\mathrm{m}$ soil layer. Agricultural mechanization should be planned according to the LBC data to prevent structural degradation of the soil, especially if the machinery passes over the area more than once.

In the LBC models for the $0.00-0.05 \mathrm{~m}$ and 0.05-0.10 $\mathrm{m}$ soil layers (Figures 4 and 5), differences in $\sigma_{\mathrm{p}}$ between crop successions decreased at higher and increased at lower soil moisture levels. These findings corroborate those of Pacheco and Cantalice (2011). In a study on a clayey Rhodic Hapludox, Garbiate et al. (2016) found that the differences in $\sigma_{p}$ between samples with higher and lower soil densities decreased with increasing soil water content. Additionally, these authors found that the solid particles were covered with water, which reduces friction between them in denser soil and increases the proximity of $\sigma_{p}$ between treatments; similar results were observed in the present study using different crop successions.

In the $0.05-0.10 \mathrm{~m}$ layer, $\mathrm{LBC}$ values were greater than those of the $0.00-0.05 \mathrm{~m}$ layer for all crop successions. Therefore, the volumetric critical soil moisture levels for machinery traffic increased (Figure 5). Critical moisture values were not established for the crop successions in the $0.5-0.10 \mathrm{~m}$ soil layer. As Araujo-Junior et al. (2011) indicated, the soil layer that is less resistant to compaction must be considered when planning machinery traffic.

Based on the LBC model for the corn/crambe succession in the $0.05-0.10 \mathrm{~m}$ layer, preconsoli- dation pressures were segregated for the regions whose volumetric soil moisture levels were $<$ or $>$ $0.37 \mathrm{~m}^{3} \mathrm{~m}^{-3}$. At this point, $\mathrm{LBC}$ inverted for this particular succession. When the volumetric soil moisture level was $<0.37 \mathrm{~m}^{3} \mathrm{~m}^{-3}$, the relative magnitudes of the LBC models were as follows: corn/canola $>$ corn/safflower $>$ corn/ sunflower $>$ corn/crambe $>$ corn/niger (Figure 5). When the volumetric soil moisture level was $>0.37 \mathrm{~m}^{3} \mathrm{~m}^{-3}$, the corn/crambe succession had the highest LBC, and all successions other than those including niger had very similar $\sigma_{\mathrm{p}}$ (Figure 5).

The corn/niger succession had the lowest LBC throughout the entire volumetric soil moisture interval because its initial soil density was lower and its soil had more macropores than those of the other crop successions.

It was found that only the corn/niger succession had low LBC values (Figs. 4 and 5). The niger crop in this succession reduced soil density, increased macroporosity, and decreased compaction, making the soil more susceptible to compression and improving its physical quality.

The crop root system may reduce soil mechanical resistance and supply organic material. Carneiro et al. (2008) found that a high supply of plant material from niger $\left(>14 \mathrm{Mg} \mathrm{ha}^{-1}\right)$ increased soil microbial activity and improved its structure. According to Souza et al. (2008), niger meets the requirements for a ground cover species because it produces $>$ $6 \mathrm{Mg} \mathrm{ha}^{-1}$ phytomass and accumulates $>100 \mathrm{~kg} /$ ha nitrogen. These characteristics increase the organic residue content in the soil and reduce soil density (Araujo-Junior et al., 2011).

Lima et al. (2012) mentioned that root system growth and development breaks up compacted soil layers, increases the volume of soil being explored, and improves water and nutrient use. When they decompose, the roots contribute to the soil carbon supply and stimulate soil microbial activity. The microorganisms form biopores, which improve the soil structure and help increase crop yield 
potential and soil resilience (Lima et al., 2012). These effects increase the physical soil quality for subsequent crops.

Niger roots may also interact with arbuscular mycorrhizal fungi (AMF). Lakshman and Channabasava (2015) investigated the colonization of niger rhizospheres with native AMF. Plants from eight production fields were analyzed. In India, this crop is considered valuable and is commonly grown for its oil. The authors found significant amounts of AMF in the niger rhizospheres and identified thirty-eight AMF species from thirteen different genera. The genus Glomus was the most predominant of all. This finding was important because a species within this genus significantly increases the yield of crops upon colonization. Mycorrhization may also have beneficial effects on successor crops. Autumn-winter crops significantly affect LLWR in the more superficial soil layers (0.00-0.05 m), especially at low soil densities. The influence of crops on the preconsolidation pressure decreases as the volumetric soil moisture content increases. The autumn-winter niger crop planted in succession to summer corn improves soil structure and is an effective alternative for crop rotation in no-tillage systems.

\section{Resumen}

A.C. Bergamin, A.C.T. Vitorino, E.A.F. Prado, F.R. Souza, M. Mauad, y L.C.F. Souza. 2018. Calidad estructural de un Latosol cultivado con oleaginosas en sucesión al maíz. Cien. Inv. Agr. 45(2): 169-180. Las operaciones mecanizadas en suelos con humedad inadecuada causan compactación y son perjudiciales para la calidad del suelo. El objetivo de este estudio fue evaluar la influencia de diferentes sucesiones de cultivos de semillas oleaginosas sobre la calidad estructural de un hapludo rubio arcilloso. Se sembraron girasol (Helianthus annuus L.), canola (Brassica napus L. y Brassica rapa), cártamo (Carthamus tinctorius L.), crambe (Crambe abyssinica Hochst.) Y niger (Guizotia abyssinica) en otoño/invierno Sistema de labranza cero en sucesión al maíz cultivado en verano y soja/maíz cultivado en verano/otoñoinvierno. Cuando comenzaron a crecer los cultivos de otoño-invierno, se recogieron muestras de suelo en cilindros metálicos de 0.0-0.05 m y 0.05-0.10 m de profundidad. Los análisis del intervalo óptimo de agua en cada sucesión de cultivos en la capa 0.0-0.05 m indicaron que las sucesiones de maíz/cártamo y maíz/crambe redujeron la calidad estructural del suelo. La cosecha niger de otoño-invierno en sucesión al maíz de verano mejoró la estructura del suelo a 0.0-0.05 m y 0.05-0.10 m en comparación con el suelo cultivado con la sucesión soja/maíz. El cultivo de níger es una alternativa eficaz de rotación de cultivos que mejora la calidad física del suelo bajo sistemas de labranza cero.

Palabras clave: Compactación del suelo, presión de preconsolidación, resistencia a la penetración del suelo. 


\section{References}

Araujo-Junior, C.F., M.S. Dias Junior, P.T.G. Guimarães, and E.N. Alcântara. 2011. Capacidade de suporte de carga e umidade crítica de um Latossolo induzida por diferentes manejos. Revista Brasileira de Ciência do Solo 35:115-131.

Bergamin, A.C., A.C.T. Vitorino, J.C. Franchini, C.M.A. Souza, and F.R. Souza. 2010. Compactação em um Latossolo Vermelho distroférrico e suas relações com o crescimento radicular do milho. Revista Brasileira de Ciência do Solo 34:681-691.

Blainski, E., A.C.A. Gonçalves, C.A. Tormena, M.V. Folegatti, and R.M.L. Guimarães. 2009. Intervalo hídrico ótimo num Nitossolo Vermelho distroférrico irrigado. Revista Brasileira de Ciência do Solo 33:273-281.

Blainski, E., C.A. Tormena, R.M.L. Guimarães, and M.R. Nanni. 2012. Qualidade física de um Latossolo sob plantio direto influenciada pela cobertura do solo. Revista Brasileira de Ciência do Solo 36:79-87.

Carneiro, M.A.C., M.A.S. Cordeiro, P.C.R. Assis, E.S. Moraes, H.S. Pereira, H.B. Paulino, and E.D. Souza. 2008. Produção de fitomassa de diferentes espécies de cobertura e suas alterações na atividade microbiana de solo de cerrado. Bragantia 67:455-462.

Dias Junior M.S., and F.J.A. Pierce. 1995. Simple procedure for estimating preconsolidation pressure from soil compression curves. Soil Technol 8:139-51.

Franchini, J.C., H. Debiasi, A.A. Balbinot junior, B.C. Tonon, J.R.B. Farias, M.C.N. Oliveira, and E. Torres. 2012. Evolution of crop yields in different tillage and cropping systems over two decades in southern Brazil. Field Crops Research 137:178-185.

Garbiate, M.V., A.C.T. Vitorino, E.A.F. Prado, M. Mauad, and D.M.P. Pellin. 2016. Hydrophysical Quality of a Latossolo and Sugarcane Yield in Chisel PlowBased Sugarcane Ratoon Management. Revista Brasileira de Ciência do Solo 41:1-10.

Imhoff, S., A.P. Silva, M.S. Dias junior, and C.A. Tormena. 2001. Quantificação de pressões críticas para o crescimento das plantas. Revista Brasileira de Ciência do Solo 25:11-18.

Imhoff, S., S.A. Pires, P.J. Ghiberto, C.A. Tormena, M.A. Pilatti, and P.L. Libardi. 2016. Physical Quality Indicators and Mechanical Behavior of Agricultural Soils of Argentina. PLoS ONE 11:1-21.

Lakshman, H.C., and A. Channabasava. 2015. Analysing arbuscular mycorrhizal fungal diversity in the rhizosphere of Guizotia abbysinica (Lf) Cass., North Karnataka, India. International Journal of Pharmacy and Biological Science 6:27-35.

Lima, V.M.P., G.C. Oliveira, M.E. Serafim, N. Curi, and A.R. Evangelista. 2012. Intervalo hídrico ótimo como indicador de melhoria da qualidade estrutural de Latossolo degradado. Revista Brasileira de Ciência do Solo 36:71-78.

Mishra, A.K., P. Aggarwal, R. Bhattacharyya, T.K. Das, and A.R. Msharma. 2015. Least limiting water range for two conservation agriculture cropping systems in India. Soil Tillage Research 150:43-56.

Pacheco, E.P., and J.R.B. Cantalice. 2011. Compressibilidade, resistência a penetração e intervalo hídrico ótimo de um Argissolo Amarelo cultivado com cana-de-açúcar nos tabuleiros costeiros de alagoas. Revista Brasileira de Ciência do Solo 35:403-415.

Pereira, A.H.F., A.C.T. Vitorino, E.A.F. Prado, A.C. Bergamin, M. Mauad, and H.P. Arantes. 2015. Least limiting water range and load bearing capacity of soil under types of tractor-trailers for mechanical harvesting of green sugarcane. Revista Brasileira de Ciências do Solo 39:1603-1610.

Safadoust, A., P. Feizee, A.A. Mahboubi, B. Gharabaghi, M.R. Mosaddeghi, and B. Ahrens. 2014. Least limiting water range as affected by soil texture andcropping system. Agricultural Water Management 136:34-41.

Silva, R.B., K.P. Lanças, V.M.F. Cardoso, and E.E.V. Miranda. 2006. Atributos físicos, mecânicos e dinâmicos do solo como indicadores do impacto do cultivo e do tráfego em perímetros irrigados. Irriga 11:384-401.

Silva, A.P., B.D. Kay, and E. Perfect. 1994. Characterization of the least limiting water range. Soil 
Science Society of America Journal 58:17751781.

Snedecor, G. W., and W.G. Cochran. 1989. Statistical methods. 8 ed. Iowa State University Press, Ames, USA.

Soil Survey Staff. 2014. Keys to soil taxonomy. 12th ed. Washington, DC: USDA-Natural Resources Conservation Service, USA.

Souza, G.S., Z.Z.M. Souza, R.B. Silva, F.S. Araújo, and R.S. Barbosa. 2012. Compressibilidade do solo e sistema radicular da cana-de-açúcar em manejo com e sem controle de tráfego. Pesquisa Agropecuária Brasileira 47:603-612.

Souza, E.D., M.A.C. Carneiro, and V.L. Banys. 2008. Fitomassa e acúmulo de nitrogênio, em espécies vegetais de cobertura do solo para um Latossolo Vermelho distroférrico de Cerrado. Acta Scientiarum Agronomy 30:525-531.

Teixeira, P.C., G.K. Donagemma, A. Fontana, and W.G. Teixeira. 2017. Manual de métodos de análise de solos. 3. Ed. Embrapa Solos, Brasília, BR. 